Images in...

\title{
Mesenteric cyst: drained and marsupialised laparoscopically avoiding enterectomy
}

\author{
Riad Al-Harfoushi, ${ }^{1}$ Lynn Stevenson, ${ }^{2}$ Norman Binnie ${ }^{1}$ \\ ${ }^{1}$ Surgery Department, Aberdeen Royal Infirmary, Aberdeen, UK; \\ ${ }^{2}$ Surgery Department, Morriston Hospital, Swansea, UK
}

Correspondence to Dr Riad Al-Harfoushi, al harfoushi@hotmail.com

\section{DESCRIPTION}

A 61-year-old man attended the outpatient department with vague abdominal discomfort associated with left flank pain. After investigation he was diagnosed with a symptomatic mesenteric cyst. US scan (figure 1) of the abdomen revealed a $20 \times 14 \times 25$ thin-walled peritoneal cyst. The cyst was laying between the spleen and the anterior aspect of the left kidney. The origin of the cyst not identified. CT scan (figure 2) confirmed the presence of a $25.7 \times 14 \times 20$ $\mathrm{cm}$ cystic lesion. The left kidney was displaced posteriorinferiorly and the spleen was displaced superiorly. The CT was also unable to successfully determine the origin of this cyst. A diagnostic laparoscopy was the best option for the patient. Intraoperatively the presence of the cyst was confirmed. It was a mesenteric cyst close to the origin of small bowel mesentery. It contained 3.3 litres of straw coloured fluid. The lining of the cyst was smooth and benign looking. Therefore, the cyst was drained and de-roofed laparoscopically and the drainage opening marsupialised.

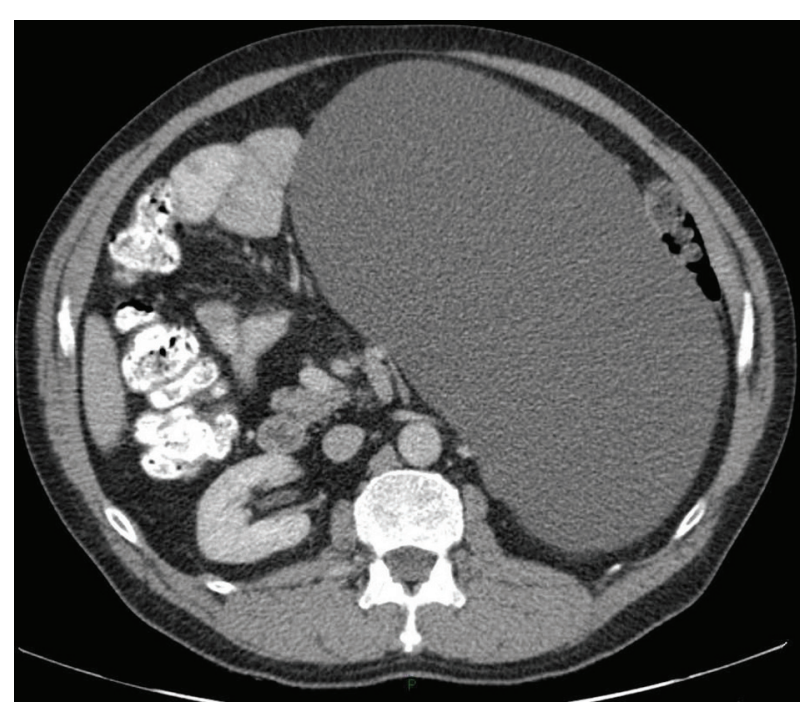

Figure 2 CT scan.

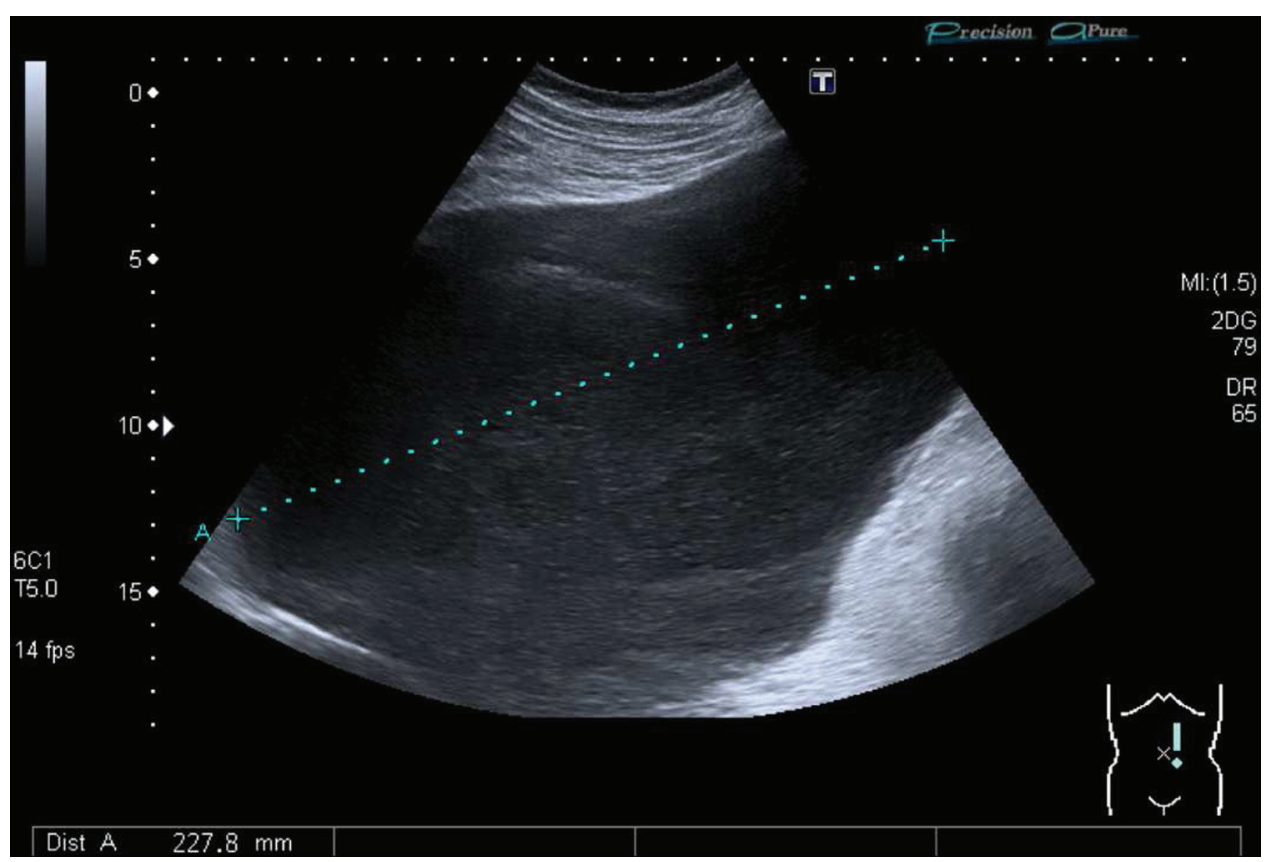

Figure 1 US scan. 


\section{BMJ Case Reports}

\section{Learning points}

- Mesenteric cysts (MC) are one of the rarest intraabdominal lesions. They are found in approximately 1 of every 100000 adult admissions to hospital. MC are of an unknown aetiology, one of the leading theories suggest that they are benign proliferations of ectopic lymphatics that fail to communicate with remaining lymphatic system. ${ }^{1}$

- Although MC are usually asymptomatic and found incidentally, they can cause vague non-specific symptoms such as: abdominal pain and distention, with possibly associated nausea and vomiting. More acute symptoms are reported with cystic rupture, haemorrhage or torsion of the cyst. Their size could range up to $10 \mathrm{~cm} .^{2}$

- The treatment of choice is surgical excision through a laparotomy or laparoscopically. If resection is not possible due to the size of the cyst or due to its location deep within the root of the mesentery, the option is partial excision with marsupialisation of the opining of the cyst into the abdominal peritoneal cavity. ${ }^{3}$

- As MC are rare, there are essentially no large clinical trials to determine optimum management. We therefore encourage all cases of $\mathrm{MC}$ to be reported so that optimum outcome can be determined.
Competing interests None.

Patient consent Obtained.

\section{REFERENCES}

1. de Perrot M, Bründler $\mathbf{M}$, Tötsch $\mathbf{M}$, et al. Mesenteric cysts. Toward less confusion? Dig Surg 2000;17:323-8.

2. Maliszewski D, Polec T, Jastrz bski T. Clasic resection of a mesenteric cyst case report and literature review. Polish Journal of Surgery 2009;81:410-13.

3. Ricketts RR. Mesenteric and omental cysts. In: Pediatric Surgery. Fifth Edition. 1998:1269-75.

This pdf has been created automatically from the final edited text and images.

Copyright 2012 BMJ Publishing Group. All rights reserved. For permission to reuse any of this content visit http://group.bmj.com/group/rights-licensing/permissions.

BMJ Case Report Fellows may re-use this article for personal use and teaching without any further permission.

Please cite this article as follows (you will need to access the article online to obtain the date of publication).

Al-Harfoushi R, Stevenson L, Binnie N. Mesenteric cyst: drained and marsupialised laparoscopically avoiding enterectomy. BMJ Case Reports 2012;10.1136/bcr.01.2012.5540, Published XXX

Become a Fellow of BMJ Case Reports today and you can:

- Submit as many cases as you like

- Enjoy fast sympathetic peer review and rapid publication of accepted articles

- Access all the published articles

- Re-use any of the published material for personal use and teaching without further permission

For information on Institutional Fellowships contact consortiasales@bmjgroup.com

Visit casereports.bmj.com for more articles like this and to become a Fellow

Keep up to date with all published cases by signing up for an alert (all we need is your email address) http://casereports.bmj.com/cgi/alerts/etoc 